\title{
Effect of Different Concentration of Paddy Straw and Cattle Dung on Biogas Production
}

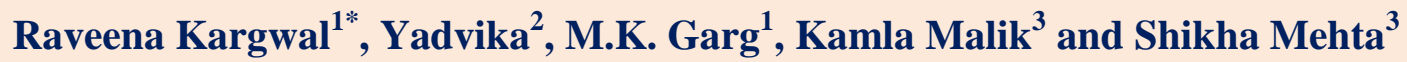 \\ ${ }^{1}$ Department of Processing and Food Engineering, COAE\&T, CCSHAU, Hisar, India \\ ${ }^{2}$ Department of Renewable and Bio Energy Engineering, COAE\&T, CCSHAU, Hisar, India \\ ${ }^{3}$ Department of Microbiology, COBS\&H, CCSHAU, Hisar, India \\ *Corresponding author
}

\begin{abstract}
A B S T R A C T
\end{abstract}
The present investigation was carried out in Renewable Energy Laboratory of the Department of Renewable and Bio Energy Engineering, College of Agriculture Engineering \& Technology,

\section{Keywords}

Paddy straw,

Cattle dung,

Biogas production,

Digester

Article Info

Accepted:

07 June 2019

Available Online:

10 July 2019
CCS Haryana Agriculture University, Hisar. Biogas production was recorded for 70 days (ten weeks) in batch type digestion. Anaerobic digestion of fresh cattle dung (CD) and paddy straw (PS) in different ratio was carried out under batch system. Paddy straw was mixed with cattle dung in different percentage 5\%,7\%, 15\%, 22.5\% and one control. Methane content in all the reactors varied between 60-62\%. Paddy straw had more cellulose (31.0) and hemicelluloses (21.1) but lesser lignin (6.0) as compared to cattle dung. Paddy straw was chopped $2-3 \mathrm{~cm}$ pieces and soaked in water overnight. Soaked paddy straw was mixed with cattle dung for preparation of different ratio. The temperature ranged from 14 to $36^{\circ} \mathrm{C}$ during ten weeks. The results indicated that biogas production was in the range of 0.63 to 5.84 1/week in digester-A and $0.73-5.87,0.98-5.40,1.10-4.98,0.57-5.851 /$ week in digester B, C, D and E. After a batch study, around 27.51-litres of biogas production was observed in reactor containing $5 \%$ paddy straw with cattle dung as compared to other reactor. As digestion period increases, the biogas production was also increased because paddy straw contain more lignin, cellulose and silica therefore it takes more time for digestion. A lot of variation in daily biogas production was also recorded due to fluctuating environmental conditions.

\section{Introduction}

Biogas is a clean environment friendly fuel as well as renewable energy source which can be a good substitution of conventional sources of energy (fossil fuels, oil) that are causing environmental as well as health problems (Yadvika et al., 2004). Biogas is an anaerobic digestion of biological material. Anaerobic digestion is a complex biological process in which microorganisms breaks down biodegradable organic substrate such as rice chaff, rice straw and rice husk as co-substrates with cow dung in the absence of oxygen and thus produced biogas (Antil et al., 2002). The benefits of anaerobic digestion are production of energy, waste treatment and odour control, improvement of hygienic conditions through reduction of pathogens, environmental advantages through protection of soil, water and air, transformation of organic wastes to high quality fertilizer. The fertilizer which 
comes from a biogas plant contains three times more nitrogen. The biogas plant is the perfect fertilizer-making machine and it has been tested all over the world. Biogas contains about 55-65\% methane $\left(\mathrm{CH}_{4}\right)$ 30-45 \% carbon dioxide $\left(\mathrm{CO}_{2}\right)$ traces of hydrogen sulphide $\left(\mathrm{H}_{2} \mathrm{~S}\right)$ and fraction of water vapour (Kapdi et al., 2008).

Paddy is a kharif season crop in India. Total food grain production of kharif season 201718 was estimated 134.67 million tones and course cereals production 31.49 million tones (Kargwal et al., 2019). Paddy straw is produced in large amount in India as well as all over the world. And its management has become a big challenge for farmers so it is burnt in field. As per 4th Advance Estimates of Indian Economy News the estimated production of major crops during 2016-17 is as under: 275.68 million tonnes of Food grains, 110.15 million tonnes of rice, 98.38 million tonnes of Wheat, 44.19 million tones of Coarse Cereals and 26.26 million tonnes of Maize. Significant quantity of unutilized/surplus crop residue that are left in the field after harvesting. Percent of unutilized/surplus crop residues of various crops are such as cereal crops $58 \%$, oil seed $7 \%$, fiber crops $23 \%$, pulses crops $2 \%$, sugarcane crops $2 \%$ and other crops $8 \%$, respectively (Anonymous. 2017). This huge amount of crop residue has economic value. Approximately 500-550 million tonnes (Mt) of crop residue is generated on-farm and offfarm annually (NPMCR, 2014).

Agriculture has a major share in the overall economy of India. In different agro-ecological regions of India, a wide range of crops are cultivated across the vast majority of land with significant quantity of crop residue (noneconomical plant parts) that is left in the field after harvest. After being used in competitive alternatives such as cattle feed, animal bedding, cooking fuel, organic manure etc., nearly 234 million tonnes/year (i.e. 30\%) of gross residue generated in India is available as surplus. Multipurpose use of crop residue include, but are not limited to, animal feeding, soil mulching, bio-manure, thatching for rural homes and fuel for domestic and industrial use. Despite the known of its benefits, growers burn a significant portion of the crop residues on-farm so that the succeeding crop can be sown on clear field. Mechanized farming coupled with lack of low-skilled farm labor and high associated cost further exacerbates the problem of on-farm burning of crop residues. Irrigated areas where multiple crops are grown annually and areas adjoining to the national capital region and satellite cities had experienced a surge in burning of rice, wheat, cotton, maize, millet, sugarcane, jute, rapeseed-mustard and groundnut residue.

In recent years, across India the demands of crop residue for cattle feed and industrial purpose has increased due to excessive in-situ burning of it. Thus, it is imperative to set up appropriate policies that promote multiple use of crop residues in the context of conservation agriculture and to prevent their on-farm burning. Anaerobic digestion of rice straw alone is inefficient because the nutrients and minerals required for microbial growth are not present at sufficient level in rice straw (Zhang and Zhang, 1999). Because of air pollution and loss of valuable organic matter and plant nutrients, burning of paddy straw is now being discouraged. The rice growers are therefore finding alternate disposal option. So codigestion of cattle dung along with paddy straw will serve as an alternate to generate energy and reduce pollution with less input and more output.

Present work is aimed to use paddy straw as supplemented raw material for biogas production along with cattle dung under anaerobic digestion conditions with the objective- Effect of co digestion of paddy straw and cattle dung on Biogas production 


\section{Materials and Methods}

The present investigation was carried out in Renewable Energy Laboratory of the Department of Renewable and Bio Energy Engineering, College of Agriculture Engineering \& Technology, CCS Haryana Agriculture University, Hisar.

\section{Substrates}

Fresh cattle dung was produced from animal farm of College of Animal Sciences, Hisar and paddy straw was collected from farmer's field.

\section{Inoculum}

Biogas slurry obtained from solid state Janta Biogas Plant of Department of Microbiology, CCSHAU, Hisar was used as inoculum for biogas production.

\section{Experimental set up of digester for biogas production}

Anaerobic digestion of fresh cattle dung and various amount of paddy straw and the developed microbial inoculum was carried out by batch system for ten weeks Aspirator bottles (capacity 5 litres each) were stopped with rubber corks fitted with glass tubes connected with rubber tubing.

One of the bottles was used as digester and other was graduated and used as gas collecting bottle.

The gas collected bottle was filled with water. The gas production in digester displaced water in the collecting bottle which was collected in third bottle. The digester was provided with an outlet which was used for feeding fresh material as well as for withdrawing the digested material. The outlet was closed with a rubber cork.

\section{Anaerobic batch digestion}

Anaerobic digestion of fresh cattle dung (CD) and paddy straw (PS) in different ratio was carried out under batch system for ten weeks. Paddy straw was chopped $2-3 \mathrm{~cm}$ pieces and soaked in water overnight. Soaked paddy straw was mixed with cattle dung for preparation of different ratio of cattle dung and paddy straw filled in lab. scale reactors such as reactor-A (Control), reactor-B $(\mathrm{CD}+5 \% \mathrm{PS})$, reactor-C $(\mathrm{CD}+7 \% \mathrm{PS})$, reactor$\mathrm{D}(\mathrm{CD}+15 \% \mathrm{PS})$, reactor-E (CD+22.5\%PS) Five digesters with different ratios of cattle dung and paddy straw were set up for analyzing their effect on biogas production.

\section{Analysis of fresh substrate, influent and effluent}

Various parameters such as $\mathrm{pH}$, total solids, volatile solids, cellulose, hemicellulose and lignin contents of Cattle dung and paddy straw were analyzed with the help of Association of Official Analytical Chemist (AOAC, 2000). The samples were also analyzed for cellulose activity, nitrogen, phosphorus and potassium content following the standard procedures (Deng and Tabatabai, 1994; Bremner, 1965; John, 1970 and Antil et al., 2002, respectively). The rate of biogas production was estimated by water displacement method.

\section{Results and Discussion}

The aim of this study was to make use of paddy straw along with cattle dung for biogas production.

\section{The analysis of fresh substrate}

Various parameters i.e. $\mathrm{pH}$, total solids, volatile solids, cellulose, hemicellulose and lignin of cattle dung and paddy straw were analyzed (Table 1). The $\mathrm{pH}$ of cattle dung and paddy straw were found to be 7.5 and 6.9 . 
Total solids (TS) and volatile solids (VS) in cattle dung was $13.7 \%$ and $83.0 \%$ while in case of paddy were found to be $94 \%$ and $85 \%$, respectively. Cattle dung were having cellulose hemicelluloses and lignin content $26 \%, 18.8 \%$ and $14.7 \%$ respectively while respective values of paddy straw were $31 \%$, $21.1 \%$ and $6.0 \%$. Percent share of nitrogen, phosphorus and potassium of total solids in cattle dung were analyzed to be 1.40, 0.54 and 1.59. Share of nitrogen, phosphorus and potassium of total solids in paddy straw were $0.69 \%, 0.12 \%$ and $0.75 \%$. Carbon and Nitrogen $(\mathrm{C} / \mathrm{N})$ ration of paddy straw and cattle dung was found to be 33.8 and 69.0 respectively.

\section{Analysis of influent}

Various parameters of influent substrate containing of different combination of cattle dung and paddy straw (reactor-A (Control), reactor-B (CD+5\%PS), reactor-C (CD+7\%PS), reactor-D (CD+15\%PS), reactor-E (CD+22.5\%PS) were analyzed (Table 2). The range of $\mathrm{pH}$ of different digesters (A, B, C, D and $\mathrm{E}$ ) was varied from 7.0-7.5. Total solids of digester A, B, C, D and $\mathrm{E}$ were found to be $12.9,12.8,12.6,12.4$ and $12.2 \%$ respectively while respective values of volatile solids were 82.0, 83.4, 85.3, 87.2 and $87.8 \%$. Cellulose and hemicelluloses content of different digesters varied from 25.8-28.5 and $18.8-21.7 \%$, respectively. Lignin content decreased with increase in amount of paddy straw supplemented to cattle dung and ranged from 12.9-14.7, respectively. Nitrogen, Phosphorus and Potassium content were highest in digester A $(1.40 \%, 0.54 \%$ and $1.57 \%$, respectively) as compared to the digester $\mathrm{B}, \mathrm{C}, \mathrm{D}$ and $\mathrm{E}$.

\section{Analysis of effluent}

Various parameters were analyzed after the completion of batch anaerobic digestion for ten weeks. The samples were withdrawn from the digested slurry (Table 3 ). The final $\mathrm{pH}$ of digesters was varied from 8.0-8.2. Total solids and volatile solids of all digesters were decreased (Table 3). The total solids of digester A, B, C, D, E were found to be 9.9, $9.8,8.8,9.4$ and $8.5 \%$ respectively while the respective value of volatile solids were 72.0, $73.4,75.3,76.2$ and $75.8 \%$.

Cellulose content of effluent was decreased (25.7, 26.4, 26.9, 27.2 and $28.1 \%$ respectively) as compare to influent $(25.8,26.7,27.8,27.9$ and $28.5 \%$, respectively). Hemicelluloses and lignin content also were decreased in effluent as compared to influent. The nitrogen content of total solid was increased from 1.40, 1.27, $1.20,1.16$ and $1.15 \%$ to $1.50,1.44,1.39,1.37$ and $1.36 \%$ in digester $\mathrm{A}, \mathrm{B}, \mathrm{C}, \mathrm{D}$ and $\mathrm{E}$, respectively.

The phosphorus and potassium content after digestion increased in effluent as compared to influent. A similar observation was reported by Shivaraj and Seenayya (1994) during methanogenesis of poultry litter waste slurry. The phosphorus and potassium content in effluent increased after ten weeks of digestion.

The biogas production was recorded for ten weeks in batch digestion (Fig. 2). The temperature ranged from $14-36^{\circ} \mathrm{C}$ during ten weeks. The biogas production increased up to $8^{\text {th }}$ week of anaerobic digestion under batch digestion conditions and then deceased up to $10^{\text {th }}$ week of incubation period probably due to depletion of substrates.

The anaerobic batch digestion for production of biogas and co-digestion of cattle dung and five different ratios of paddy straw was conducted using five litres capacity aspirators. The maximum biogas production was observed in co-digestion of cow dung and $5 \%$ PS followed by control, co-digestion of CD+7\%PS, CD+15\%PS, CD+22.5\%PS. 
Table.1 Analysis of various parameters of fresh substrates (Cattle dung and paddy straw)

\begin{tabular}{|l|c|c|}
\hline Parameter & Cattle dung & Paddy straw \\
\hline pH & 7.5 & 6.9 \\
\hline Total solid (\%) & 13.7 & 94 \\
\hline Volatile solid (\%) & 83.0 & 85 \\
\hline Cellulose (\% of TS) & 26.0 & 31 \\
\hline Hemicellulose (\% of TS) & 18.8 & 21.1 \\
\hline Lignin (\% of TS) & 14.7 & 6.0 \\
\hline Nitrogen (\% of TS) & 1.40 & 0.69 \\
\hline Phosphorus(\% of TS) & 0.54 & 0.12 \\
\hline Potassium(\% of TS) & 1.59 & 0.75 \\
\hline C/N ratio & 33.8 & 69.0 \\
\hline
\end{tabular}

Table.2 Analysis of various parameters of the influent used in anaerobic digestion

\begin{tabular}{|l|c|c|c|c|c|}
\hline \multirow{2}{*}{ Parameter } & A & B & C & D & E \\
\cline { 2 - 5 } & Control & CD+5\%PS & CD+7\%PS & CD+15\%PS & CD+22.5\%PS \\
\hline pH & 7.50 & 7.12 & 7.26 & 7.17 & 7.00 \\
\hline Total solid (\%) & 12.9 & 12.8 & 12.6 & 12.4 & 12.2 \\
\hline Volatile solid (\%) & 82.0 & 83.4 & 85.3 & 87.2 & 87.8 \\
\hline Cellulose (\% of TS) & 25.8 & 26.7 & 27.8 & 27.9 & 28.5 \\
\hline Hemicellulose (\% of & 18.8 & 19.8 & 20.0 & 21.4 & 21.7 \\
TS) & & & & & \\
\hline Lignin (\% of TS) & 14.7 & 13.7 & 13.5 & 13.4 & 12.9 \\
\hline Nitrogen (\% of TS) & 1.40 & 1.27 & 1.20 & 1.16 & 1.15 \\
\hline Phosphorus(\% of TS) & 0.54 & 0.52 & 0.43 & 0.42 & 0.41 \\
\hline Potassium(\% of TS) & 1.59 & 1.58 & 1.54 & 1.53 & 1.52 \\
\hline
\end{tabular}

Table.3 Analysis of various parameters of effluent used in anaerobic digestion

\begin{tabular}{|l|c|c|c|c|c|}
\hline Parameter & $\mathbf{A}$ & $\mathbf{B}$ & $\mathbf{C}$ & $\mathbf{D}$ & $\mathbf{E}$ \\
\cline { 2 - 5 } & Control & CD+5\%PS & CD+7\%PS & CD+15\%PS & CD+22.5\%PS \\
\hline pH & 8.2 & 8.1 & 8.0 & 8.0 & 8.00 \\
\hline Total solid (\%) & 9.9 & 9.8 & 8.8 & 9.4 & 8.5 \\
\hline Volatile solid (\%) & 72.0 & 73.4 & 75.3 & 76.2 & 75.8 \\
\hline Cellulose (\% of TS) & 25.7 & 26.4 & 26.9 & 27.2 & 28.1 \\
\hline Hemicellulose (\% of & 17.8 & 18.8 & 19.1 & 20.6 & 20.5 \\
TS) & & & & & \\
\hline Lignin (\% of TS) & 14.2 & 13.1 & 12.9 & 12.4 & 12.3 \\
\hline Nitrogen (\% of TS) & 1.50 & 1.44 & 1.39 & 1.37 & 1.36 \\
\hline Phosphorus(\% of TS) & 0.57 & 0.54 & 0.53 & 0.47 & 0.45 \\
\hline Potassium(\% of TS) & 1.57 & 1.57 & 1.48 & 1.47 & 1.46 \\
\hline
\end{tabular}


Fig.1 Weekly biogas production (Litres) with co digestion of cattle dung and different ratios paddy straw

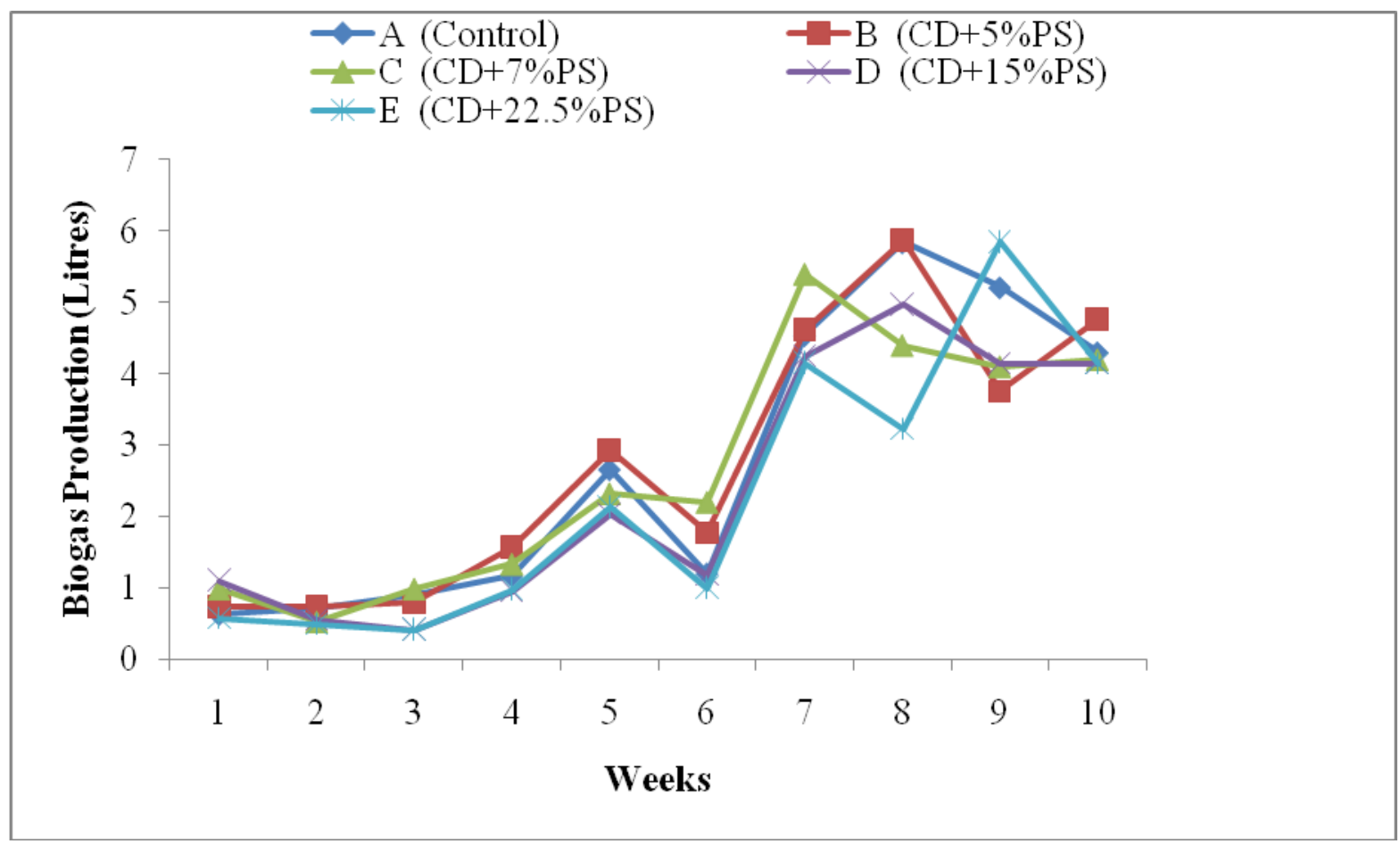

Fig.2 Total biogas production

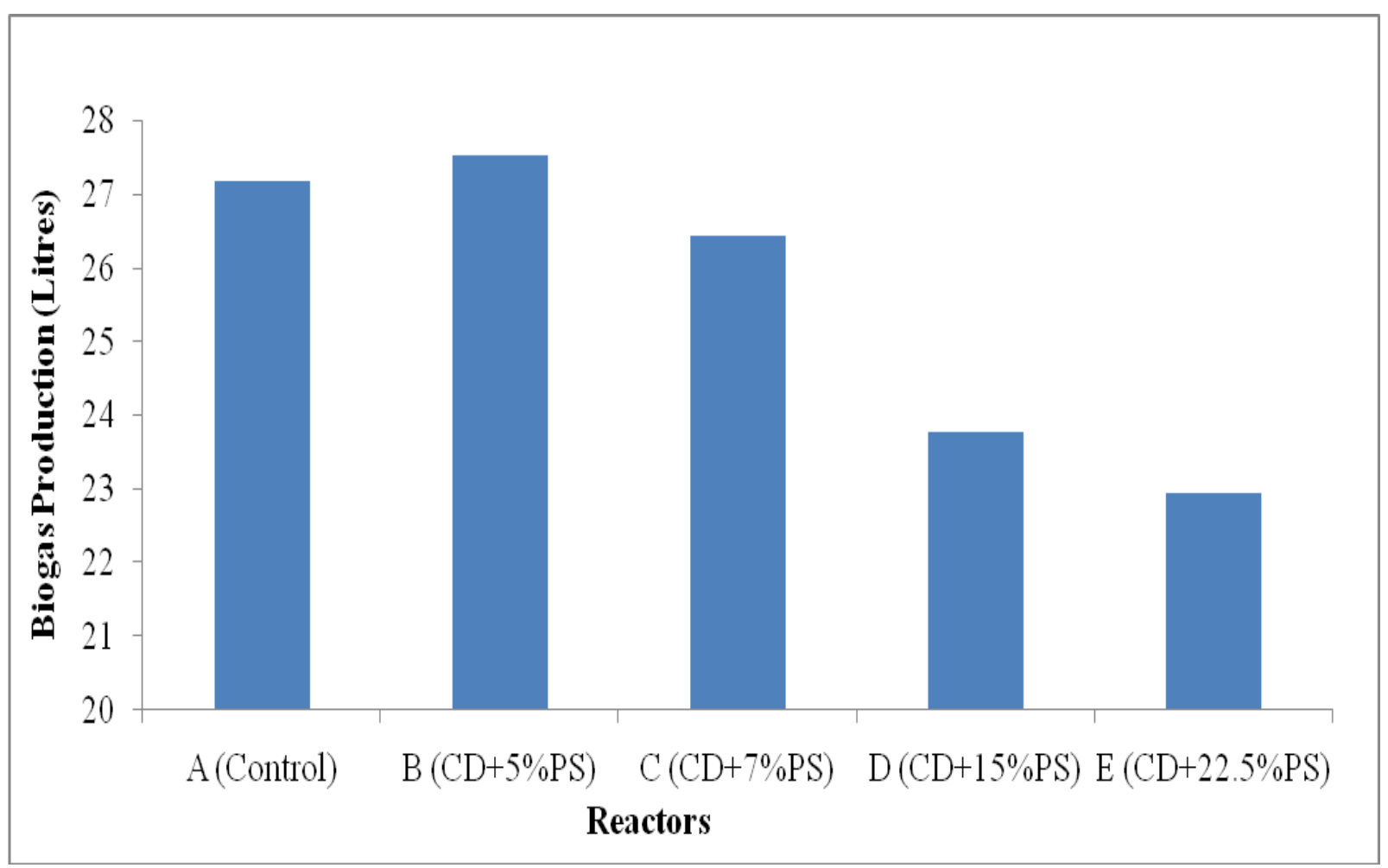




\section{Biogas production}

Biogas production was recorded for ten weeks in batch type digestion. The temperature ranged from $14-36^{\circ} \mathrm{C}$ during ten weeks. The biogas production ranged from 0.635.841 /week in digester-A and 0.73-5.87, 0.98$5.40,1.10-4.98,0.57-5.851 /$ week in digester B, C, D and E (Fig. 1). Biogas production in starting weeks was less and in last week's more because temperature variation and paddy straw takes more time for digestion. The biogas production increased up to $8^{\text {th }}$ week of anaerobic digestion under batch digestion conditions and then started deceasing up to $10^{\text {th }}$ week of incubation period probably due to depletion of substrates. Result was after ten weeks study highest gas produced in digester B as compare to others.

The anaerobic batch digestion for production of biogas and co-digestion of five different percentage of paddy straw (Control, $\mathrm{CD}+5 \% \mathrm{PS}, \quad \mathrm{CD}+7 \% \mathrm{PS}, \quad \mathrm{CD}+15 \% \mathrm{PS}$, $\mathrm{CD}+22.5 \% \mathrm{PS}$ ) was conducted using lab. scale reactors of five litres capacity (Fig. 2). The maximum biogas production (27.51litre) was observed in reactor-B (CD+5\%PS) followed by reactor-A (Control), reactor- $\mathrm{C}$ (CD+7\% PS), reactor-D (CD+15\%PS), reactor-E $(\mathrm{CD}+22.5 \% \mathrm{PS})$. This study resulted increase the biogas production by adding little amount of paddy straw in cattle dung. These findings are similar to ones available in literature (Adhikari et al., 2015).

In conclusion, supplementation of paddy straw to cattle dung analyzed the effect on biogas production. Paddy straw was mixed with cattle dung in different percentage 5\%, $7 \%, 15 \%, 22.5 \%$ and one control. Paddy straw had more cellulose (31.0) and hemicelluloses (21.1) but lesser lignin (6.0) as compared to cattle dung. As such digestion period increase rate of biogas production increased because paddy straw contain more lignin, cellulose and silica therefore it takes more time for digestion, so it reducing degradability by ruminal microorganisms. The maximum biogas production (27.51 litres) was observed on supplementation of cattle dung with 5\% paddy straw. A lot of variation in daily biogas production was also recorded due to fluctuating environmental conditions. As no increase in biogas production has been achieved after supplementation of higher percentage of paddy straw to cattle dung so use of higher percent of paddy straw may be avoided.

The cattle manure is endowed with a considerable biogas production potential evaluated through anaerobic decomposition that offers numerous benefits of environmental, agricultural and socioeconomic standards.

The gap between demand and supply for energy sources can be reduced by converting bio degradable agricultural residues into a biogas. It is a source of renewable green energy. The biogas can be used as a cooking gas and also can be used in turbine to generate electricity. The left over sludge can be packed and used as a manure and compost for agriculture farming.

Rice straw is promising for biogas cosubstrate. The addition of rice straw as cosubstrate little improve total biogas yield. It also reduces air pollution, find eco-friendly disposal methods, generate revenue from the waste that is generation of wealth from the waste and reduce global warming.

\section{References}

Adhikari, S.K., Sims, R. E. H., Hasslet, S., Murray, P. and Steward-withers, R. 2015. Improving Biogas Production Efficiency through Co-digestion of Cattle Dung with Crop Residues: a Case 
Study in Nepal Proceeding of Ninth International Conference on sensing technology, pp 803-810.

Anonymous. 2017. Agricultural Statistics Division Directorate of Economics \& Statistics Department of Agriculture, Cooperation and Farmers Welfare First Advance Estimates of Production of Food grains for 2017-18.

Antil, R.S., Singh, A. and Dahiya, S.S., 2002. Practical Manual of siol and plant analysis. Department of Soil Science, CCS Haryana Agric. Univ.

Bremmer, J. M., 1965. Determination of nitrogen in soil by Kjeldahl method. $J$. Agric. Sci. 55: 11-33.

Deng, S.P. and M.A. Tabatabai, 1994. Cellulase activity of soils. Soil Biol. Biochem., 26(10): 1347-1354.

John, M. K., 1970. Calorimeter determination of phosphorus in soil and plant materials with ascorbic acid. Soil Sci., 109: 214-220.

Kapdi, S.S., Vijay, V.K., Rajesh, S.K., Rajendra, P., 2008. Biogas scrubbing, compression and storage. Perspective and prospective in Indian context. Centre for Rural Development and technology, Indian Institute of technology, New Delhi, India.

Kargwal, R., Yadvika, Garg, M.K., Singh, V.K., and Yadav, Y.K., 2019. Energy Auditing of Pearl Millet Production System in Dry land Region of Haryana Agricultural University in Hisar, India.
International journal of agricultural engineering, 12 (2), (in press).

Nagamani, B. and Ramasamy, K., 1999. Biogas production technology: an Indian perspective. Curr. Sci. 77: 44-54. NPM\&CR, 2014. Government of India Ministry of Agriculture Department of Agriculture \& Cooperation (Natural Resource Management Division) Krishi Bhawan, New Delhi.

Sayyed, R. Z. and Patil, A. S. (eds.) Scientific Publishers, India, pp: 137-142.

Shivaraj D. and Seenayya G., 1994. Optimum total solids content for the generation of biogas from poultry litter waste. Indian Journal of Environmental Health, 36:115-118.

Wati, L., Kapoor, K. K. and Kundu B. S., 2009. Cattle dung based modified solid state janta Biogas plant. In: Biotechnology Emerging Trend.

Yadvika, Santosh, T.R. Sreekrishnan, S. Kohli and V. Rana, 2004. Enhancement of biogas production from solid substrates using different techniques-a review. Biores. Technol., 95: 1-10.

Zhang, R. and Zhang, Z. 1999. Biogasification of paddy rice straw with an anaerobic-phased solids digester system, Biores. Technol., 68: 235-245.

Ziauddin, Z. and Rajesh, P., 2015. Production and analysis of biogas from kitchen waste. International Research Journal of Engineering and Technology pp: $622-632$.

\section{How to cite this article:}

Raveena Kargwal, Yadvika, M.K. Garg, Kamla Malik and Shikha Mehta. 2019. Effect of Different Concentration of Paddy Straw and Cattle Dung on Biogas Production. Int.J.Curr.Microbiol.App.Sci. 8(07): 537-544. doi: https://doi.org/10.20546/ijcmas.2019.807.066 